\title{
Australian Journal of Crop Science \\ Application of arbuscular mycorrhizal fungi accelerates the growth of shoot roots of sugarcane seedlings in the nursery
}

\author{
Wawan Sulistiono ${ }^{1 *}$, Taryono ${ }^{2}$, Prapto Yudono ${ }^{2}$, Irham ${ }^{2}$ \\ ${ }^{1}$ Assessment Institute for Agricultural Technology of North Maluku, Sofifi, Indonesia \\ ${ }^{2}$ Faculty of Agriculture, Universitas Gadjah Mada, Yogyakarta Indonesia, JI. Flora Bulaksumur Yogyakarta, Indonesia
}

*Corresponding author: tionojanah@gmail.com

\begin{abstract}
Shoot roots are second type of root, which emerge from the base of the new shoots, 5-7 days after planting. The shoot roots growth on single bud chips seedling is critical for further growth in dry land. The objectives of this study were to examine shoot root growth using different doses of arbuscular mycorrhizal fungi (AMF) inoculum on five clones of sugarcane and to ascertain their effect on seedling biomass weight. The highest and lowest temperatures on the research site were $32 \circ$ and $18 \stackrel{\circ}{ }$, in tropical monsoon climate. The experimental design was a completely randomized design (CRD) in $4 \times 5$ factorial arrangement with four replicates. The treatments were: four doses of $A M F$ inoculum $(0,1,2,3 \mathrm{~g} /$ bud chips) on five clones with single bud chips seedling (PS864, KK, PS881, BL, and VMC). The evaluated parameters were root colonization affected by doses of AMF inoculum, number of shoot roots, surface area of shoot and total roots, root length, biomass seedling, and P leaf concentration affected by doses of AMF inoculum. AMF inoculum doses of 2 and $3 \mathrm{~g}$ of inoculum/bud chips resulted in the speed and extent root colonization at 5 days after inoculation on all five sugarcane clones. The clones exhibited $57-100 \%$ accelerated emergence of shoot roots (i.e. the second roots formed), increased total root length, total root surface area especially on BL, VMC, and P leaf concentration. Application of 2 3 inoculum/bud of AMF inoculum significantly increased shoot roots growth i.e. root length, root surface area, and number of shoot roots.
\end{abstract}

Keywords: Sugarcane seedlings, Arbuscular mycorrhiza fungi, Shoot roots, Growth, Nursery.

Abbreviations: AMF_arbuscular mycorrhizal fungi; CRD_completely randomized design; P_phosphate; DAIS_days after inoculation and sowing; LPPM_Lembaga Penelitian dan Pengabdian Kepada Masyarakat; UGM_Universitas Gadjah Mada.

\section{Introduction}

There are many constraints on the growth of sugarcane in dryland such as soil moisture and low fertility (Gana, 2011; Zhao et al., 2010; Sulistiono et al., 2017a), so that the growth of roots does not develop optimally (Aquino and Medina 2014; Ohashi et al., 2015). Roots are essential for different functions during plant development including plant anchorage (Rebouillat et al., 2009), water and mineral nutrient uptake (Chang-xing et al., 2004), and improves soil physical conditions (Aos et al., 2016). The concern over sugarcane rooting system growth is important because the responsiveness of sugarcane is determined directly and indirectly by the growth and function of rooting system. Sulistiono et al. (2016b) reported that the weight of millable cane is determined by root parameters such as root surface area, root diameter, and root:shoots dry weight ratio. However, the roots also change because of soil environment resulting in a decrease in diameter and root length (Lovelli et al., 2012).

The improvement of root development in sugarcane has often been focused on the effect of the application of mycorrhizal inoculum on the rooting system, such as root diameter and root fresh weight (Souza et al., 2015a), fresh and dry weight of root biomass and the induction of the rooting system (Kelly et al., 2005; Otto et al., 2009). It is known that mycorrhizae colonize and thrive the rooting system of sugarcane cultivated by non-destructive rhizosphere (Azevedo et al., 2014). It is known that growth of the rooting system of sugarcane can be increased with mycorrhizal infection. A study by Sulistiono et al. (2016b) reported that application of AMF increased the traits of roots i.e. root lenght, root surface area, root diameter, root dry weight, and the root:shoots dry weight ratio of sugarcane transplanted in dry land. In general, this effort of the infection of plants by colonization of plant roots with certain beneficial microbes "including mycorrhizae" causes the induction of a unique physiological state called priming (Conrath et al., 2006). Bernal et al. (2008) reported that priming by using Gluconacetobacter diazothropicus bacteria during transplanting enhanced the emission of functional roots of sugarcane and significant improvement in the percentage of survival.

However, less attention has been given to the induction of the shoot rooting system at the application of mycorrhizal inoculum on sugarcane seedlings. This is important because shoot roots play a vital role in further growth such as shoot 
roots development as well as water and nutrients uptake for the growing shoots in futher growth (Smith et al., 2005).

The growth of plant cane in the field is influenced and determined by the development of the rooting system especially in the future growth in dry land (Sulistiono et al., $2017 \mathrm{~b})$. In the development of sugarcane rooting system, the first roots formed are sett roots, which emerge from a band of root primordia, and the second formed are shoot roots, which emerge from the base of the new shoot (Smith et al., 2005). In the soil that undergoes water stress, a decrease in sugarcane root fresh weight occurs (Souza et al., 2015b) and depth reached by roots (Laclau and Laclau, 2009). Therefore, to improve the rooting system of sugarcane it is very important to study the application of mycorrhiza on the shoot root growth and even an increase of biomass of seedlings, especially in shoot roots growth on single bud chips seedling before transplanting.

The objectives of this study were to examine root colonization by mycorrhiza treatments and its effect on shoots and sett roots of sugarcane bud chips seedlings in the nursery. Therefore, the hypothesis that application of AMF accelerates the growth of shoot roots can be investigated. The effect of the development of shoot roots on increased biomass of seedlings and $P$ concentration in the leaf is also studied.

\section{Results}

\section{Colonization of roots by $A M F$}

Colonization of root was very significantly $(P<0.01)$ affected by the interaction of mycorrhizal inoculum dose and clones at the ages of 5-30 days after inoculation and sowing (DAIS). These colonization were relatively fixed at the age of 10-30 DAIS. Colonization of root by AMF dose of 2-3 g/seedlings enhanced the speed of the colonization of the seedlings compared with the control (without mycorrhizal inoculation). The colonization of the roots achieved 57-100 $\%$ at the age of 5 days after inoculation (Table 1 ). Mycorrhizal colonization reached maximum at the age of 20 DAIS.

Colonization without mycorrhiza reached $46-47 \%$ at the ages of 20-30 DAIS due to the influence of indigeneous mycorrhiza. However, this colonization was significantly different from the application of mycorrhizal inoculum at 2-3 $\mathrm{g} /$ seedling. Colonization was characterized by the structure of mycorrhizal hyphae or vesicles and arbuscular. Based on infection observation in the early inoculation of colonization, many hyphaes and vesicles were often found and at the ages of 20-30 DAIS (Fig 1 ).

The plant root colonization varied with the type of clone and level of doses of AMF inoculum. Colonization of VMC was the lowest in the early inoculation, reaching $57 \%$ with inoculum dose of $2 \mathrm{~g} /$ seedling (Table 1). AMF inoculation of $2 \mathrm{~g} / \mathrm{seed}$ significantly accelerated maximum colonization compared with treatment of dose of $1 \mathrm{~g} /$ seed and without mycorrhiza at the age of 10 DAIS to clone PS8 64, PS881 and $\mathrm{BL}$. This indicated that the ability of these clones are genetically more responsive to mycorrhizal inoculation.

\section{Morphological characteristics of total root}

\section{Surface area of total roots}

The clone, inoculation treatment and their interaction had significant effect $(P<0.01)$ on the total roots surface area at 40 DAIS. BL clone had the highest response to inoculation treatment. Inoculation treatment with 2-3 g AMF inoculum doses significantly increased the total roots surface area on $\mathrm{BL}$ clone. The total root length of PS864 clone significantly increased with high doses $(3 \mathrm{~g} / \mathrm{seed})$. For the other clones, there were no increase in the total roots surface area with an increase in AMF inoculum (Table 2).

\section{Number of sett roots}

The interaction between clone and inoculation treatment had significant effect $(P<0.01)$ on the number of sett roots at 40 DAIS. The AMF inoculum treatment did not significantly increase the number of sett roots in all seedling sugarcane clones except clone PS864 in 2-3g/seeds doses of AMF inoculum. These results suggest that application of mycorrhiza did not improve the sett roots growth (number of roots sett). This indicates that infection of mycorrhiza at 40 DAIS was not active on sett root of sugarcane.

\section{Morphological characteristics of shoot roots}

\section{Percentage of emergence of shoot roots}

The clone, inoculation treatment, and their interaction had significant effect $(P<0.01)$ on shoot roots of seedlings at 20 40 DAIS. Prior to 20 DAIS, in all combination of treatments, shoot roots on seedlings were not detectable (Fig 3). In the early emergence of shoot roots, i.e. 20 and 25 DAIS, the number of shoot roots per seeds was one with an average length of $1 \mathrm{~cm}$ (data not shown). Together with the growth of the plant, at the age of 40 DAIS, there was a significant difference in the number of shoot roots and it was the effect of the treatment of AMF doses (Table 3).

\section{Number of shoot roots}

The number of shoots roots was the highest with $2 \mathrm{~g}$ AMF inoculum/seeds application and it significantly increased compared with control (without mycorrhizal application) of seeds (Table 3 ). The number of shoot roots significantly (genetically) varied with the type of the clones. BL clone is genetically capable to produces the highest number of shoot roots.

\section{Surface area of shoot roots}

The clone, AMF inoculation treatments, and their interaction had significant effects $(P<0.01)$ on the shoot roots surface area. These interactions showed that the mycorrhizal inoculum dose application had a different effect among clones on shoot roots suface area. The AMF inoculation had different responses among clones to improve the shoot 
Tabel 1. The effect of mycorrhizal inoculum doses in colonization of roots on five sugarcane seedling clones.

\begin{tabular}{|c|c|c|c|c|c|c|c|}
\hline \multirow{2}{*}{ Clones } & \multirow{2}{*}{$\begin{array}{l}\text { Doses of AMF inoculum } \\
\text { (g/seedling) }\end{array}$} & \multicolumn{6}{|c|}{ Dates ages days after inoculation and sowing } \\
\hline & & 5 & 10 & 15 & 20 & 30 & 40 \\
\hline \multirow[t]{4}{*}{ PS864 } & 3 & $100 \mathrm{a}$ & $100 \mathrm{a}$ & $100 \mathrm{a}$ & $100 \mathrm{a}$ & 83.3def & 98.3 \\
\hline & 2 & $97.4 \mathrm{abc}$ & $100 \mathrm{a}$ & $100 \mathrm{a}$ & $100 \mathrm{a}$ & $92.5 \mathrm{a}-\mathrm{d}$ & 96.7 \\
\hline & 1 & 70.1 efg & $77.5 \mathrm{~b}-\mathrm{d}$ & 83.5ef & $100 \mathrm{a}$ & $59.6 \mathrm{gh}$ & 73.3 \\
\hline & 0 & $34.5 \mathrm{ij}$ & $42.1 \mathrm{e}$ & $43.6 \mathrm{~h}$ & $46.5 \mathrm{e}$ & $49.2 \mathrm{~h}$ & 41.7 \\
\hline \multirow[t]{4}{*}{ KK } & 3 & $94.2 \mathrm{a}-\mathrm{d}$ & $76.5 \mathrm{~cd}$ & $92.5 \mathrm{bc}$ & $97.5 a b$ & $93.3 a-d$ & 100 \\
\hline & 2 & 89.2 b-e & $90.0 \mathrm{~b}$ & $77.5 \mathrm{fg}$ & $85 \mathrm{~cd}$ & $85.0 \mathrm{c}-\mathrm{f}$ & 95.0 \\
\hline & 1 & $95.0 \mathrm{abc}$ & 97.5 b & $70.0 \mathrm{~g}$ & $100 \mathrm{a}$ & $97.5 a b$ & 71.7 \\
\hline & 0 & $33.3 \mathrm{j}$ & $47.5 \mathrm{e}$ & $72.5 \mathrm{~g}$ & $97.5 \mathrm{ab}$ & 77.5 ef & 63.3 \\
\hline \multirow[t]{4}{*}{ PS881 } & 3 & $90.0 \mathrm{~b}-\mathrm{d}$ & $100 \mathrm{a}$ & $100 \mathrm{a}$ & $100 \mathrm{a}$ & 90.0 b-e & 96.7 \\
\hline & 2 & $95.0 \mathrm{ab}$ & $100 \mathrm{a}$ & $100 \mathrm{a}$ & $100 \mathrm{a}$ & 90.0 b-e & 83.3 \\
\hline & 1 & $80.0 c-f$ & 92.1 bc & $100 \mathrm{a}$ & $100 \mathrm{a}$ & $74.2 \mathrm{fg}$ & 70.0 \\
\hline & 0 & $62.5 \mathrm{fgh}$ & $80 b-d$ & $97.5 a b$ & $95 a-c$ & $67.5 \mathrm{f}-\mathrm{h}$ & 51.7 \\
\hline \multirow[t]{4}{*}{$\mathrm{BL}$} & 3 & $91.6 \mathrm{a}-\mathrm{d}$ & $100 \mathrm{a}$ & $85.0 \mathrm{e}$ & $100 \mathrm{a}$ & $97.5 \mathrm{ab}$ & 100 \\
\hline & 2 & 80.0 d-g & $100 \mathrm{a}$ & $92.5 \mathrm{~cd}$ & $97.5 \mathrm{ab}$ & $98.2 \mathrm{a}-\mathrm{c}$ & 88.3 \\
\hline & 1 & $67.5 \mathrm{fg}$ & $71.7 \mathrm{~cd}$ & $69.43 \mathrm{~g}$ & 95 a-c & $85.0 \mathrm{~d}-\mathrm{f}$ & 53.3 \\
\hline & 0 & $40.2 \mathrm{hij}$ & $75.8 \mathrm{~cd}$ & $80.83 \mathrm{e}-\mathrm{g}$ & $89.2 \mathrm{~cd}$ & $85.0 \mathrm{~d}-\mathrm{f}$ & 58.3 \\
\hline \multirow[t]{4}{*}{ VMC } & 3 & $84.6 c-f$ & $100 \mathrm{a}$ & $100 \mathrm{a}$ & $100 \mathrm{a}$ & $100 \mathrm{a}$ & 95.0 \\
\hline & 2 & 57.7 ghi & 86.6 b-d & $100 \mathrm{a}$ & $100 \mathrm{a}$ & $100 \mathrm{a}$ & 88.3 \\
\hline & 1 & $62.5 \mathrm{fgh}$ & $83.3 b-d$ & $100 \mathrm{a}$ & $100 \mathrm{a}$ & $100 \mathrm{a}$ & 70.0 \\
\hline & 0 & $26.11 \mathrm{j}$ & $70.0 \mathrm{~d}$ & $86.7 \mathrm{de}$ & $95.0 \mathrm{bc}$ & 96.7 a-d & 58.3 \\
\hline
\end{tabular}

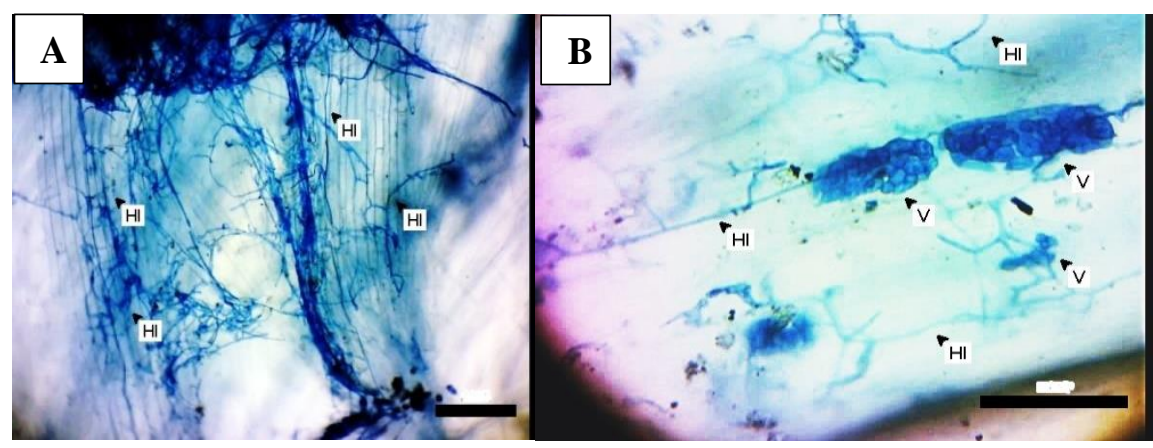

Fig 1. Colonization on BL clone at the age of 10 (A) and 20 days after inoculation (B). Hi: Hyphae; V: vesicle. Scala bar: 10 $\mu \mathrm{m}$. Objective $10 \mathrm{x}$.

Table 2. The effect of interaction on root traits of seedling at the age of 40 days after inoculation and sowing.

\begin{tabular}{|c|c|c|c|c|c|c|}
\hline Clones & $\begin{array}{l}\text { Doses of } \\
\text { Inoculum } \\
\text { (g/seeds) }\end{array}$ & $\begin{array}{c}\text { Shoot roots surface } \\
\text { area }\left(\mathrm{cm}^{2}\right)\end{array}$ & $\begin{array}{c}\text { Total roots } \\
\text { surface area } \\
\left(\mathrm{cm}^{2}\right)\end{array}$ & $\begin{array}{c}\text { Shoot roots } \\
\text { fresh weight }(\mathrm{g})\end{array}$ & $\begin{array}{c}\text { Biomass } \\
\text { (g fresh weight) }\end{array}$ & $\begin{array}{c}\text { P concentration } \\
\text { of leaf }(\%)\end{array}$ \\
\hline PS864 & 3 & $38.65 b c$ & 65,60 b-d & $1.47 \mathrm{ab}$ & $20.43 \mathrm{ab}$ & $0.39 \mathrm{f}-\mathrm{h}$ \\
\hline PS864 & 2 & 27.18 b-e & 48,62 b-f & $1.07 \mathrm{ac}$ & $12.62 \mathrm{c}$ & $0.37 \mathrm{gh}$ \\
\hline PS864 & 1 & 16.15 c-e & $43,85 \mathrm{~d}-\mathrm{f}$ & $1.58 \mathrm{a}$ & $5.79 \mathrm{~d}-\mathrm{f}$ & $0.47 b-d$ \\
\hline PS864 & 0 & $4.00 \mathrm{e}$ & $39,25 \mathrm{f}$ & $0.08 \mathrm{e}$ & $6.25 \mathrm{~d}-\mathrm{f}$ & $0.39 \mathrm{f}-\mathrm{h}$ \\
\hline KK & 3 & $38.70 \mathrm{bc}$ & $66,50 \mathrm{~b}-\mathrm{d}$ & $1.21 \mathrm{a}-\mathrm{c}$ & $17.03 \mathrm{~b}$ & $0.43 c-f$ \\
\hline KK & 2 & $13.43 c-e$ & $59,00 \mathrm{~b}-\mathrm{f}$ & $0.22 \mathrm{de}$ & $8.28 \mathrm{de}$ & $0.48 \mathrm{bc}$ \\
\hline KK & 1 & $6.38 \mathrm{e}$ & $45,00 c-f$ & $0.12 \mathrm{de}$ & $9.56 \mathrm{~cd}$ & 0.40 e-g \\
\hline KK & 0 & $19.18 c-e$ & $63,00 \mathrm{~b}-\mathrm{e}$ & $0.26 \mathrm{de}$ & $6.12 \mathrm{~d}-\mathrm{f}$ & $0.42 \mathrm{~d}-\mathrm{g}$ \\
\hline PS881 & 3 & $39.43 \mathrm{bc}$ & $57,15 b-f$ & $0.91 \mathrm{a}-\mathrm{d}$ & $22.84 a$ & $0.48 \mathrm{bc}$ \\
\hline PS881 & 2 & $53.95 a b$ & $70,50 \mathrm{~b}$ & $0.74 \mathrm{~b}-\mathrm{e}$ & $16.71 b$ & $0.50 \mathrm{ab}$ \\
\hline PS881 & 1 & $9.38 \mathrm{de}$ & $50,25 b-f$ & $0.17 \mathrm{de}$ & $6.26 \mathrm{~d}-\mathrm{f}$ & $0.46 b-d$ \\
\hline PS881 & 0 & $6.98 \mathrm{de}$ & 101,75 a & $1.08 \mathrm{a}-\mathrm{c}$ & $5.18 d-f$ & $0.39 \mathrm{f}-\mathrm{h}$ \\
\hline $\mathrm{BL}$ & 3 & $47.85 \mathrm{ab}$ & $95,57 \mathrm{a}$ & 0.61 c-e & $8.24 \mathrm{de}$ & 0.44 c-e \\
\hline$B L$ & 2 & $67.63 \mathrm{a}$ & $61,00 \mathrm{~b}-\mathrm{f}$ & $0.75 b-e$ & $9.27 \mathrm{~cd}$ & $0.48 \mathrm{bc}$ \\
\hline$B L$ & 1 & $35.45 b-d$ & $63,50 \mathrm{~b}-\mathrm{d}$ & $0.14 \mathrm{~d}-\mathrm{e}$ & $5.10 \mathrm{~d}-\mathrm{f}$ & $0.54 a$ \\
\hline $\mathrm{BL}$ & 0 & $13.25 \mathrm{c}-\mathrm{e}$ & $67,00 \mathrm{bc}$ & $1.14 \mathrm{a}-\mathrm{c}$ & $3.11 \mathrm{f}$ & $0.46 \mathrm{~b}-\mathrm{d}$ \\
\hline VMC & 3 & $14.55 \mathrm{c}-\mathrm{e}$ & $62,50 \mathrm{~b}-\mathrm{e}$ & $0.15 \mathrm{de}$ & $6.06 \mathrm{~d}-\mathrm{f}$ & $0.37 \mathrm{gh}$ \\
\hline VMC & 2 & $8.85 \mathrm{de}$ & $65,50 \mathrm{~b}-\mathrm{d}$ & $0.12 \mathrm{de}$ & 4.67 ef & $0.34 \mathrm{~h}$ \\
\hline VMC & 1 & $16.10 \mathrm{c}-\mathrm{e}$ & 40,82 ef & $0.12 \mathrm{de}$ & 4.46 ef & $0.34 \mathrm{~h}$ \\
\hline VMC & 0 & 13.65 c-e & $65,60 \mathrm{~b}-\mathrm{d}$ & $0.17 \mathrm{de}$ & 4.06 ef & $0.22 \mathrm{i}$ \\
\hline
\end{tabular}




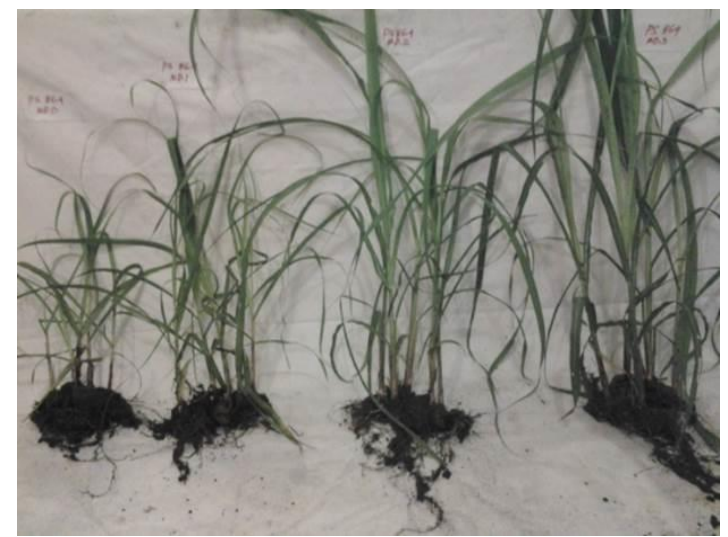

Fig 2. The effect of AMF doses on performance of seedling at 40 days after inoculation and sowing (DAIS). From left to right, the growth of the rooting system and shoots effected by the $0,1,2,3 \mathrm{~g}$ of inoculum of AMF/seed.

Table 3. The effect of AMF doses level on number of shoot roots at the age of 40 days after inoculation and sowing.

\begin{tabular}{cl}
\hline Doses of AMF (g/seeds) & Number of shoot roots \\
\hline 0 & $1.60 \mathrm{~b}$ \\
1 & $2.80 \mathrm{ab}$ \\
2 & $4.00 \mathrm{a}$ \\
3 & $3.95 \mathrm{a}$
\end{tabular}

Remarks: Different letters in same column represents significant differences by Duncan's Multiple Range Test at $5 \%$ level.
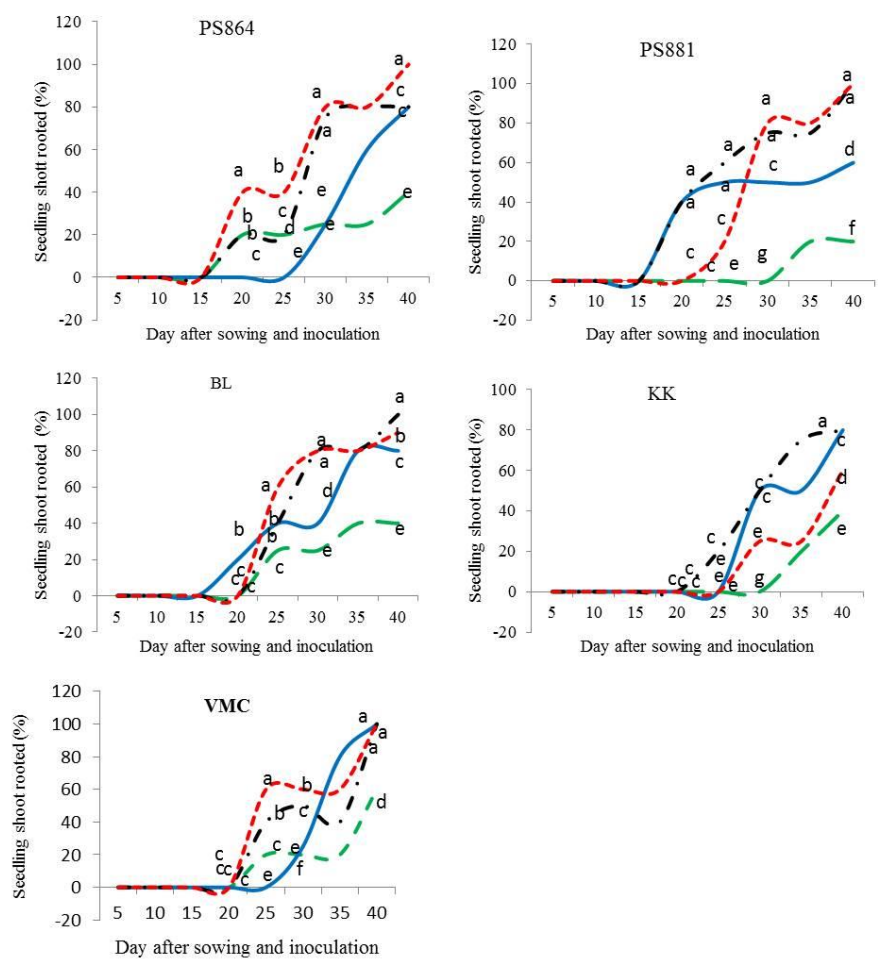

$$
=-0 \mathrm{~g} \text { /sed } \quad-1 \mathrm{gseed}
$$

Fig 3. Effect of mycorrhiza doses on time of shoot roots emergence on single bud chips seedlings in the nursery. Different letters in same days after sowing and inoculation on each clones represents differences by Duncan's Multiple Range Test at $5 \%$ level.

roots surface area (Table 2). All clones were more responsive to the application of 2-3 g AMF inoculum/seeds in increasing the shoot root surface area except KK, and the treatment produced higher surface area of shoot roots.

\section{Fresh weight of shoot roots}

There was a significant interaction $(p<0.01)$ between AMF treatments and clones in affecting the shoot roots fresh weight. The application of 1-3 g AMF significantly improve the fresh weight of shoot root seedlings in the PS864 clone, and KK clone produced higher shoot root fresh weight at 3 $\mathrm{g} /$ seeds than the control (Table 2).

\section{Biomass of seedlings and $P$ concentration of leaf}

The clone, mycorrhiza treatment and their interaction had significant effects $(p<0.01)$ on the biomass of seedlings and $P$ 
concentration of the leaves. The application of AMF inoculum at the doses of 2-3 g/seed significantly increased the biomass of seedlings except on VMC clone (Table 2 and Fig 2).

The treatment with mycorrhizal doses produced higher $\mathrm{P}$ concentration in leaves of all clones, compared with control treatment (without inoculation). The $\mathrm{P}$ concentration in leaves was increased significantly in the AMF inoculum dose of $1 \mathrm{~g} / \mathrm{seeds}$ than control treatment of all clones, except clone KK. Increase in P concentration of leaves was linear with increasing doses of inoculum on VMC clones, whereas the highest of $\mathrm{P}$ concentration of leaves in PS864 and BL clones accurred in AMF dose of $1 \mathrm{~g} / \mathrm{seed}$, and $2 \mathrm{~g} /$ seed in KK and PS881 clones (Table 2).

\section{Discussion}

The application of 2-3 g inoculum/seeds doses of AMF inoculum was able to enhance and accelerate the colonization of roots on sugarcane single bud chip seedling with the innoculation of 7.2-10.7 spores. This result complements with the report from Kelly et al. (2005) that the amount of spore density up to 4 spores/g soil influenced root colonization. Kumar et al. (2016) suggested that spore abundance was a good indicator of soil with AMF potential. The colonization of roots by AMF (2-3 g inoculum/seeds) at the early inoculation varied among clones especially in the VMC clone that produced the lowest colonization. This is possibly caused by the genotypic effect on root colonization by mycorrhiza.

The genotypic effect of plant's ability for root colonization and mycorrhization according by Nagata et al. (2016) is determined by the ability of host plant to produce jasmonic acid (JA) and secretion into root exudates. The quality and source of exudates from host/non host-plant play an important role in triggering the germination of mycorrhiza spore (Shwetha and Lakshman, 2011). Furthermore, a signal of protein symbiosis as mycorrhizal induced small secreted protein 7 (MiSSP7) in the host's roots, which also found as a determinant of root colonization (Plett et al., 2011).

The application of 2-3 g AMF inoculum/seeds influenced the increased morphological characteristics on total roots of sugarcane seedlings. The effect varied among clones. For example, the doses of 2-3 $\mathrm{g}$ inoculum produced greater increase in the total root surface area in BL clone and these doses increased the number of sett roots in PS864. These results are consistent with the finding from Basak et al. (2011) which suggest that mycorrhiza treatment with $10 \mathrm{~g}$ spore/plant increased the weight of roots on tomato seedlings. Aka-Kaçar et al. (2010) reported that mycorrhizal inoculation induced root dry weight of cherry. In this study, it is shown that the dose levels on spore were lower than those reported by Basak et al. (2011) but could improve the total root surface area. This result indicates that number of 7.2-10.7 spore was the optimum for increasing the growth of total root on sugarcane bud chips seedlings.

The application of AMF inoculum (1-3 g/seeds) increased and accelerated the emergence of shoot root in the germination phase of sugarcane compared with the control (Fig.3). The emergence of sugarcane shoot roots particularly by the effect of treatment of mycorrhiza has been very rarely reported. Silva et al. (2015) reported that endophytic bacteria (Herbaspirillum spp. and Bacillus spp.) increases rooting of sugarcane seedling. In general, it has been stated that the shoot roots emerge from the base of the newshoot, 5-7 days after planting (Smith et al., 2005). In this study, the shoot roots could emerge at 20 days after planting and it was accelerated by increasing the spore doses (3.6-10.7 spore/g inoculum/seeds), compared with control.

The inoculum doses had different effects among clones regarding to the time required for shoot roots emergence (Fig. 3). This was possibly related to the interaction between mycorrhiza and plant genotypes. High density of spores had more ability for germination and root penetration, especially in the recognition mechanism of the fungus to the specific host plants (Sieverding, 1991). This symbiosis has been related to the ability of the host plant to produce the fungal sugar transporter (MST2), which is likely to be the major transporter supplying the fungus with carbon from plant host (Eckardt 2011). It has been related to the initial fungushost plant recognition and early colonization by simbiotic C$P$ trade between the host plant and fungus (Smith and Smith, 2012). According to Lopes et al. (2012), there are different responsiveness among the sugarcane clones to soil organisms such as strain of $A$. brasilense due to the clone's capacity to respond to inoculation.

There was significantly positive correlation between the percentage of shoot root emergence and root colonization at 5 days after inoculation with $r^{2}=0.32^{* *}$. These suggest that the increase of root colonization could improve and accelerate the emergence of shoot roots. The root colonization was also positively correlated with the morphological characteristics of shoot roots i.e. root surface area and number of shoot roots with correlation values of $0.33^{* *}$ and $0.25^{*}$, respectively. This indicates that the density of AMF spore could improve root colonization and influenced rooting process of shoot roots. This was in accordance with Smith et al. (2005) and Ohashi et al. (2015) that higher root growth in sugarcane at the early growth is required to support the growth of shoots.

High root colonization at the early inoculation is followed by the increase in the fresh weight of biomass seedling and $P$ concentration of leaf with correlation values of $0.51^{* *}$ and $0.35^{* *}$ at 40 DAIS. These results were consistent with the findings from other researches which suggest that mycorrhizal application enhanced the growth rate (shoot and roots dry weight) of sugarcane at the age of 40 and 80 days (Reddy et al., 2004), and increased the growth performance of M. alba L. seedlings (Lu et al., 2015). Furthermore, the root colonization by Glomus intraradices and total external mycelium correlated positively with shoot's $P$ concentration and total dry weight of Citrus limonia (Nogueira and Cardoso, 2006). Another report also showed that biofertilizers (from rocks and organic matter) inoculated with diazotrophic bacteria increased sugarcane dry biomass i.e. tops, leaves, and stalks (Oliveira et al., 2015). These results indicated that the application of mycorrhiza (2-3 g inoculum/seeds) improved shoot growth (biomass weight) and shoot root of sugarcane bud chips seedling.

The increase of biomass sugarcane seedlling at level 2-3 $\mathrm{g}$ AMF inoculum/seeds was caused by the faster increase in colonization (Table 1). In this condition, the structure of arbuscles and vesicles were formed. The amount of carbon transferred to the rooting system positively correlated with the presence of vesicles in the rooting system (Finlay, 2008; 
Miyasaka and Habte, 2011). Vesicles were used for the structural development of mycorrhizal fungi storage (Sieverding, 1991; Finlay, 2008; Miyasaka and Habte, 2011). This might explain the increased biomass of sugarcane seedling by the effect of AMF inoculum doses, which was correlated with the growth of shoot roots.

In general, application of AMF inoculum (1-3 g/seeds) significantly increased $\mathrm{P}$ concentration on the leaves of all clones but varied among clones. The increasing $P$ uptake was related to the ability of root colonization (Gaur and Adholeya, 1999; Marschner, 1995; Smith et al., 2011). From this study, the root colonization had a positive corelation with $\mathrm{P}$ contents of the leaf of sugarcane seedling with $r^{2}=$ $0.35^{* *}$.

\section{Materials and Methods}

\section{Plant materials}

The propagules of sugarcane seeds were in the form of single bud chips. Bud chips are planting materials in the form of single buds with small tissue. The cane seeds consist of 4 clones ie Bululawang (BL), PS881, PS864, Kidangkencana (KK), and VMC. The seed materials were obtained from a 7month-old plant from the Madukismo sugar factory seed garden, Yogyakarta.

\section{Location and climate}

The experiments were conducted in Harjobinangun $(600 \mathrm{~m}$ a.s.I., S: 07040'16" and E: 110E24'14") Sleman district, Special region of Yogyakarta, Indonesia and according to Koppen's classification, belongs to tropical monsoon climate (Climate-Data-org, 2016). The highest and the lowest temperatures on research site were $32 \circ$ and $18 \stackrel{\circ}{\circ}$, respectively.

\section{Strains of arbuscular mycorrhizal fungi (AMF)}

The AMF inoculum was in the form of zeolitic granular media. The doses of spore of AMF inoculum was $3.6 \mathrm{spore} / \mathrm{g}$ zeolite granular media. The AMF was obtained by collecting the fungi from various regions in Java island of Indonesia. Some genera of AMF obtained from isolation by a different experimental team were Glomus sp., Funneliformis sp., Acaulospora sp., Gigaspora sp., and Scutellospora sp.

\section{Experimental design and application of arbuscular mycorrhizal fungi (AMF)}

The experimental design was a Completely Randomized Design (CRD) arranged in a $5 \times 4$ factorial with 4 replications, including five sugarcane clones: PS864, KK, PS881, BL, and VMC; four rates of arbuscular mycorrhizal fungi (AMF) inoculum dose consisted of 1, 2, 3 g mycorrhizal inoculum /seeds, and the control (without application of mycorrhiza). The AMF inoculum rate for enhance roots seedlings in the nursery followed the report for Basak et al. (2011).

The number of propagules used for each treatment combination was 50 single buds with four replications. The experiment was conducted by raising the seedlings of bud chips in polybags ( $8 \times 12 \mathrm{~cm}$ size of polybag). The application of mycorrhiza inoculum was done shortly after the bud chips were placed into the polybags in the nursery.

\section{Colonization of roots by AMF.}

The infection percentage (colonization) was measured by using modified Clearing and Staining (Kormanik and McGraw, 1982). Sixty root cuttings $(1 \mathrm{~cm})$ per treatment unit were randomly chosen from the 9 sample plants.

\section{Root length, root surface area and number of shoot roots}

Measurement of the root length and root surface area was done using area meter. Measurement of the root length and root surface area was done using the method of line intersection perfected by Indradewa (2002) according to Tennant (1975). In order to obtain the root surface area, roots were assumed to be cylindrical so that the root projection area $=2 \mathrm{RL}$ with $\mathrm{R}$ was the radius, $\mathrm{L}$ was the root length. The root surface area was the area of the cylinder bark without cover at both of the root edges, i.e. circumference multiplied with root length $=2 \pi R L$. The number of shoot roots was determined by calculating the shoot root that emerged from the base of the new shoots.

\section{Biomass assessment and $P$ analysis}

The fresh biomass weight was measured by weighing the seedling that removed from the planting medium and separated from the fresh weight of nodes (single bud chip). At the harvest of each polybags on each combination of treatment, the total fresh biomass (fresh weight of root and shoots) was recorded. Shoots were separated from roots. Roots were separated from the soil by washing with running under a tap water. The $P$ concentration of leaves was measured using dry ashing method. The $P$ concentration was measured with Spectrophotometer UV-VIS. Chemical analysis was carried out using the procedures issued by Yoshida et al. (1997).

\section{Measurements}

Five days after sowing, the root colonization and roots morphological characteristcs were examined. The next measurement was conducted every five-days interval until 40 DAIS. The measured variables were root colonization, surface area of total roots, number of shoot roots, surface area of shoot roots, percentage of emergence of shoot roots, shoot roots of fresh weight, fresh weight of biomass seedlings, and $P$ leaf concentration. The measurements of fresh biomass of seedlings and $P$ uptake were conducted at 40 DAIS.

\section{Statistical analysis}

The data were analyzed according to the intervals of observation with analysis of variance (ANOVA) of factorial CRD using SAS 9 program for Windows. If there was an interaction between factors, a comparison of the interaction effects was made. Then, the treatment effects were compared based on Duncan's Multiple Range Test at $p \leq$ 0.05. To test the correlation SAS 9 was used. 


\section{Conclusion}

The AMF inoculum dose of 2-3 g/seeds, containing 7.2-10.7 spore is the optimum level for application in sugarcane bud chips seedlings. The level of 2-3 g AMF inoculum increased speed and extent of root colonization, accelerated the emergence of shoot roots and shoot root growth characteristics i.e. root surface area, number of shoot roots, and fresh weight of shoot roots. The level of 2-3 $g$ also resulted in higher biomass and the leaf $P$ concentration of sugarcane seedlings in the nursery.

\section{Acknowledgments}

The authors acknowledge the financial suport for the institute of research and community service, Lembaga Penelitian dan Pengabdian Kepada Masyarakat (LPPM) Universitas Gadjah Mada of Yogyakarta Indonesia, grant No. UGM/396/LIT/2014, and Scholarship of Doctoral Program by the Indonesian Agency for Agriculture Research and Development, Ministry of Agriculture.

\section{References}

Aka-kacar Y, Akpinar C, Agar A, Yalcin-Mendi Y, Serce S, Ortas I (2010) The effect of mycorrhiza in nutrient uptake and biomass of cherry rootstocks during acclimatization. Rumanian Biothechnological Letters. 15(3):5246-5252.

Aos, Sulistyawati E, Syamsudin TS (2016) Influence of cropping system on root distribution of annual crops. J Agron. 16 (1):12-22.

Aquino GS, Medina CC (2014) Productividade e indices biometricos e fisiolocos de cana-de-acucar cultivada sob diferentes quantidades de palhada. Pesq Agropec Bras. 49(3):173-180.

Azevedo LCB, Stürmer SL, Lambais MR (2014) Early changes in arbuscular mycorrhiza development in sugarcane under two harvest management systems. Braz J Microbiol. 45(3):995-1005.

Basak H, Demir K, Kasim R, Okay, FY (2011) The effect of endo-mycorrhiza (VAM) treatment on growth of tomato seedling grown under saline conditions. Afr J Agric Res. 6(11):2532-2538

Bernal A, Machado P, Cortegaza L, Carmona ER, Rivero O, Zayas CM, Nodarse O, Perez A, Santana I, Arencibia AD (2008) Priming and biopriming integrated into the sugarcane micropropagation technology by temporary immersion bioreactors (TIBS). Sugar Tech. 10(1):42-47.

Chang-xing Z, Xing-ping D, Sui-Qi Z, Qing Y, Steudle E, Lun S (2004) Advance in the studies on water uptake by plant roots. Acta Bot Sini. 46(5):505-514.

Conrath U, Beckers GJM, Flors V, Agustín PG, Jakab G, Mauch F, Newman MA, Pieterse CMJ, Poinssot B, Pozo MJ, Pugin A, Schaffrath U,Ton J, Wendehenne D, Zimmerli L, and Mani BM (2006) Priming: Getting Ready for Battle. Mol Plant Microb Interact. 19(10):1062-1071.

Eckardt NA (2011) A symbiotic sugar transporter in the arbuscular mycorrhizal fungus Glomus sp. Plant Cell. 23(10):3561.

Gana AK (2011) Cowdung: Soil amendment agent for the sandy upland sugarcane ecology in Nigeria. J Agric Technol. 7:497-505.

Finlay RD (2008) Ecological aspects of mycorrhizal symbiosis: with special emphasis on the functional diversity of interactions involving the extraradical mycelium. J Exp Bot. 5:111.

Gaur A, Adholeya V (1999) Mycorrhizal effect on the acclimatization, survival, growth and chlorophyll of micro propagated syngonium and draceana inoculated at weaning and hardening stages. Mycorrhiza. 9:215-219.

Indradewa D (2002) Gatra agronomis dan fisiologis pengaruh genangan dalam parit pada tanaman kedelai. Ph.D. Dissertation. Universitas Gadjah Mada. Yogyakarta. Indonesian.

Kelly RM, Edwadrs DG, Thompson JP, Magarey RC (2005) Growth responses of sugarcane to mycorrhizal spore density and phosphorus rate. Aust J Agric Res. 56:14051413.

Kormanik PP, McGraw AC (1982) Quantification of vesiculararbuscular mycorrhizae in plant roots. In: Method and Principles of Mycorrhizal research, Schenck, N.C (Ed.) The American Phytopathological Society. St.Paul. M.N. pp:3745.

Kumar V, Kumar R, Anal AKD (2016) Spore population, colonization, species diversity, and factors influencing the association of arbuscular mycorrhizal fungi with litche tress in India. J Environ Biol. 37:91-100.

Laclau PB, Laclau JP (2009) Growth of the whole root system for a plant crop of sugarcane under rainfed and irrigated environments in Brazil. Field Crops Research. 114 (3):351360.

Lu N, Zhou X, Cui M, Yu M, Zhou J, Qin Y, Li Y (2015) Colonization with arbuscular mycorrhizal fungi promotes the growth of Morus Alba $\mathrm{L}$ seedlings under greenhouse conditions. Forests. 6(3):734-747.

Lopes VR, Filho JCB, Araujo LM, Rodrigues FV, Daros, E, Oliveira RA (2012) The selection of sugarcane families that display better associations with plant growth promoting rhizobacteria. J Agron. 11(2):43-52.

Lovelli S, Perniola M, Tommaso TD, Bochicchio R, Amato M (2012) Specific root length and diameter of hydroponicallygrowth tomato plant under salinity. J Agron. 11(4):101106.

Marscher H (1995) Mineral nutrition of higher plants. Academic Press. London.

Miyasaka SC, Habte M (2011) Plant mechanisms and mycorrhizal symbiosis to increase phosphorus uptake efficiency. Commun. Soil Sci Plant Anal. 32:1101-1147.

Nagata $M$, Yamamoto $N$, Miyamoto $T$, Shimomura A, Arima S, Hirsch AN, Suzuki A (2016) Enhanced hyphal growth of arbuscular mycorrhizae by root exudates derived from hight R/FR treated Lotus japonicus. Plant Signaling Behavior. 11(6):1-4.

Nogueira MA, Cardoso EJBN (2006) Plant growth and phosphorus uptake in mycorrhizal rangpur lime seedlings under different levels of phosphorus. Pesq Agropec Bras. 41(1):93-99.

Ohashi AY P, Pires RCM, Ribeiro RV, Silva ALBO (2015) Root growth and distribution in sugarcane cultivars fertigated by a surface drip system. Bragantia. 74(2):1-9.

Oliveira FLN, Stamford NP, Neto DS, Oliveira ECA, Oliveira WS, Santos CERS (2015) Effects of biofertilizers produced from rocks and organic matter, enriched by diazotrophic 
bacteria inoculation on growth and yield of sugarcane. Aust J Crop Sci. 9(6):505-508.

Otto R, Trivelin PCO, Franco HCJF, Faroni CC, Vitti AC (2009) Root system distribution of sugarcane as related to nitrogen fertilization, evaluated by two methods monolith and probes (1). R Bras Ci Solo. 33(5):601-611.

Plett JM, Kemppainen M, Kale SD, Kohler A, Legue V, Brum A, Tyler BM, Pardo AG, Martin F (2011) A secreted effector protein of Laccaria bicolor is required for symbiosis development. Curr Biol. 21(14):1197-1203.

Rebouillat J, Dievart A, Verdeil JL, Escoute J, Giese G, Breitler JC, Gantet P, Espeout S, Guiderdoni E, Perin C (2009) Molecular Genetics of Rice Root Development. Rice. (2):15-34.

Reddy CN, Bharati BK, Rajkumar HG, Sunanda DN (2004) Infectivity and efficacy of four native vesicular-arbuscular mycorrhiza fungi on sugarcane (cv CO 419). Mycorrhiza News. 16(2):9-12.

Shwetha C, Lakshman HC (2011) Association of arbuscular mycorrhizal fungi in some plants of amaranthaceae. Karnataka J Agric Sci. 24(3):303-308.

Sieverding E (1991) Vesicular-arbuscular mycorrhiza management in tropical agrosystem. Deutsche Gesellschaft für Technische Zusammenarbeit (GTZ) GmbH. Technical Cooperation-Federal Republic of Germany.

Silva JM, Santos TMC, Albuquerque LS, Montaldo YC, Oliveira JUL, Silva SGM, Nascimento MS, Teixeira RRO (2015) Potential of the endophytic bacteria (Herbaspirillum spp. and Bacillus spp.) to promote sugarcane growth. Aust J Crop Sci. 9(8):754-760.

Smith DM, Inman-Bamber NG, Thorburn PJ (2005) Growth and function of the sugarcane root system. Field Crops Res. 92:169-183.
Smith SE, Jakobsen I, Gronlund M, Smith FA (2011) Roles of arbuscular mycorrhizas in plant phosphorus nutrition: interactions between pathways of phosphorus uptake in arbuscular mycorrhizal roots have important implications for understandingand manipulating plant phosphorus acquisition. Plant Physiol. 156(3):1050-1057.

Smith SA, Smith FA (2012) Fresh perspective on the roles of arbuscular mycorrhizal fungi in plant nutrition and growth. Mycology.104:1-13.

Souza CCM, Pedrosa EMR, Rolim MM, Cavalcante UMT, Juniar IPM, Filho JVP (2015 $)$ Initial development and chemical components of sugarcane under water stress associated with arbuscular mycorrhizal fungi. Rev Bras Eng Agric Ambient. 19(6):548-552.

Souza GS, Souza ZM, Cooper M, Tormena CA $\left(2015^{b}\right)$ Controlled traffic and soil physical quality of an oxisol under sugarcane cultivation. Sci Agric. 72(3):270-277.

Sulistiono W, Taryono, Yudono P, Irham (2017a) Earlyarbuscular mycorrhizal fungi- application improved physiological performances of sugarcane seedling and further growth in the dry land. J Agric Sci. 9:95-108.

Sulistiono W, Taryono, Yudono P, Irham (2017b) Sugarcane roots dynamics inoculated with arbuscular mycorrhizal fungi on dry land. J Agron. 16(3):101-114.

Tennant D (1975) A test of a modified line intersect method of estimating root length. Journal of Ecology. 63:995-1001.

Yoshida S, Forno DA, Cock JH, Gomez KA (1997) Laboratory manual for physiological studies of rice. Second Edition. Los Banos. IRRI. Laguna Philippines. 70p.

Zhao D, Glaz B, Comstock JC (2010) Sugarcane response to water-deficit stress during early growth on organic and sand soils. Am J Agric Biol Sci. 5(3):403-414. 